\title{
KONFERENCJA \\ „PRÓBA USTROJOWEJ REKONSTRUKCJI KRÓLESTWA POLSKIEGO W LATACH 1861-1862. W 150. ROCZNICE REFORM MARGRABIEGO ALEKSANDRA WIELOPOLSKIEGO"
}

W dniach 28-29 maja 2012 roku w Centrum Szkoleniowym Straży Granicznej w Kętrzynie w związku z przypadającą na 2012 rok sto pięćdziesiątą rocznicą reform margrabiego Aleksandra Wielopolskiego miała miejsce Konferencja zatytułowana Próba ustrojowej rekonstrukcji Królestwa Polskiego w latach 1861-1862. Pomysłodawcami realizacji tego przedsięwzięcia był prof. zw. dr hab. Dariusz Szpoper z Wydziału Prawa i Administracji Uniwersytetu Gdańskiego oraz prof. dr hab. Lech Mażewski z Wydziału Prawa i Administracji Uniwersytetu Warmińsko-Mazurskiego. Konferencję zorganizowała Katedra Historii Państwa i Prawa Polskiego działająca na Wydziale Prawa i Administracji Uniwersytetu Warmińsko-Mazurskiego, przy znaczącym organizacyjnym wsparciu przedsięwzięcia okazanym przez dziekana Wydziału Prawa i Administracji Uniwersytetu Warmińsko-Mazurskiego prof. zw. dr. hab. Bronisława Sitka.

Obrady rozpoczęły się od wygłoszenia przez prof. zw. dr. hab. Dariusza Szpopera referatu wprowadzającego zatytułowanego Aleksander Wielopolski i próba ustrojowej rekonstrukcji Królestwa Polskiego w latach 1861-1862. Następnie uczestnicy sympozjum wygłosili referaty składające się na trzy bloki tematyczne. W pierwszym dniu obrad w ramach pierwszej sekcji, Rosja, administracja Królestwa Polskiego i Kościót wobec reform Wielopolskiego, wystapił z referatem Stosunek Rosji i jej elit do reform Wielopolskiego dr Henryk Głębocki (Uniwersytet Jagielloński). W tej czę́ci obrad wziął również udział prof. Igor Chrostoforow (Uniwersytet Moskiewski im. M. Łomonosowa, Uniwersytet w Princeton), który wygłosił referat zatytułowany Nacjonalizm i Wielkie Reformy: Aleksander Wielopolski i rosyjska polityka wewnętrzna w latach 1850-1860. Głos następnie zabrał prof. dr hab. Lech Mażewski (Uniwersytet Warmińsko-Mazurski), który swe wystąpienie poświęcił zagadnieniu Roli administracji Królestwa Polskiego w sformutowaniu i realizacji reform Wielopolskiego, oraz ks. prof. dr hab. Mieczysław Różański (Uniwersytet Warmińsko-Mazurski), który przedstawił referat zatytułowany Ksiadz arcybiskup Zygmunt Felinski wobec reform Wielopolskiego.

W drugiej części dnia w sekcji Polskie elity wobec reform Wielopolskiego przedstawiono cztery referaty autorstwa następujących prelegentów: dr. Przemysława Dąbrowskiego z Uniwersytetu Gdańskiego - „Litewski Wielopolski”, czyli program hrabiego Wiktora Starzeńskiego; dr. Bartłomieja Garczyka z Uniwersytetu im. Adama Mickiewicza w Poznaniu - Józef Miniszewski: publicystyka w shużbie reform Wielopolskiego; dr. Wojciecha Turka z Gdańska - „Czerwoni” wobec reform Aleksandra Wielopolskiego: zdecydowanie przeciw oraz Biali wobec reform Aleksandra Wielopolskiego: za mało.

W drugim dniu sympozjum w czasie obrad sekcji Reformy Wielopolskiego z perspektywy czasu uczestnicy wygłosili następujące referaty: prof. zw. dr hab. Bogdan Szlachta (Uniwersytet Jagielloński) - Miejsce Wielopolskiego w historii polskiego konserwatyzmu; prof. dr hab. Lech Mażewski - Amnestia z 12 kwietnia 1863 r. Czy możliwe było połqczenie reform Wielopolskiego z uwłaszczeniem chłopów na zasa- 
dach określonych w dekrecie Tymczasowego Rzqdu Narodowego z 22 stycznia 1863 roku?; prof. dr hab. Adam Wielomski (Uniwersytet Przyrodniczo-Humanistyczny w Siedlcach) - Wielopolski a rozumienie polityki w XLX wieku; dr Grzegorz Smyk Demontaż reform Wielopolskiego; dr Anna Klimaszewska (Uniwersytet Gdański) i dr Michał Gałędek (Uniwersytet Gdański) - Wielopolski jako punkt odniesienia dla myśli polityczno-ustrojowej stańczyków. Dwudniowe obrady i prelekcje podsumowal prof. zw. dr hab. Dariusz Szpoper.

Plonem konferencji stał się wydany we wrześniu 2012 roku nakładem Uniwersytetu Warmińsko-Mazurskiego w Olsztynie zbiór artykułów pod redakcją prof. Lecha Mażewskiego, zatytułowany Próba ustrojowej rekonstrukcji Królestwa Polskiego w latach 1861-1862. W 150. rocznice reform margrabiego Aleksandra Wielopolskiego.

MIKOEAJ TARKOWSKI (Gdańsk)

\section{POSTĘPOWANIE HABILITACYJNE DRA LUKASZA MACHAJA}

Dnia 23 kwietnia 2012 roku Rada Wydziału Prawa, Administracji i Ekonomii Uniwersytetu Wrocławskiego nadała stopień naukowy doktora habilitowanego nauk prawnych w dyscyplinie prawo doktorowi Łukaszowi Machajowi, adiunktowi w Katedrze Doktryn Politycznych i Prawnych na Wydziale Prawa, Administracji i Ekonomii Uniwersytetu Wrocławskiego. Postępowanie habilitacyjne odbyło się według nowej procedury ustanowionej w rezultacie nowelizacji ustawy o stopniach naukowych i tytule naukowym oraz o stopniach i tytule w zakresie sztuki z dnia 18 marca 2011 roku. Podstawą postępowania była monografia pt. Wypowiedzi symboliczne w orzecznictwie Sqdu Najwyższego Stanów Zjednoczonych, poświęcona analizie wyroków SN USA, wydawanych na podstawie konstytucyjnej klauzuli wolności słowa, w kwestii swobody podejmowania niewerbalnych zachowań wyrażających określone idee, poglądy czy emocje. Oprócz tej monografii dorobek naukowy habilitanta po uzyskaniu przezeń stopnia naukowego doktora (2005) obejmował także książkę będącą zmodyfikowaną wersją rozprawy doktorskiej, 24 artykuły w czasopismach naukowych (w tym 7 współautorskich), 20 rozdziałów w pracach zbiorowych (w tym 5 współautorskich), pracę redakcyjna, 15 haseł leksykonowych, krótkie opracowanie monograficzne (współautorskie) oraz 7 recenzji i artykułów recenzyjnych.

Decyzję Rady Wydziału poprzedziła jednomyślna pozytywna opinia na temat osiągnięć naukowych dr. Machaja sporządzona przez Komisję Habilitacyjną powołaną w jego sprawie przez Centralną Komisję ds. Stopni i Tytułów, w której skład wchodzili: prof. dr hab. Henryk Olszewski (przewodniczący), prof. dr hab. Hubert Izdebski, prof. dr hab. Ryszard M. Małajny, prof. dr hab. Andrzej Sylwestrzak (recenzenci), prof. dr hab. Marek Maciejewski, dr hab. Maria Zmierczak, prof. UAM (członkowie Komisji) oraz dr hab. Maciej Marszał, prof. UWr (sekretarz Komisji). 